\title{
The Great Fossil Enigma: The Search for the Conodont Animal
}

Simon J. Knell. 2012. Indiana University Press, Bloomington. Pp. 440. $\$ 45.00$ (cloth), 25 b \& w illustrations. ISBN 9780253006042.

Reviewed by E. N. Anderson

Reviewer address: Department of Anthropology, University of California Riverside. eugene.anderson@ucr.edu

Received: February 14, 2013

Volume: 4:37-38

Published: March 10, 2013

(C) 2013 Society of Ethnobiology

On page 356, Simon Knell admits: "I positioned myself, like an anthropologist, on the edge of this scientific community...." No wonder the book is of interest to ethnobiologists. It is, in fact, something of an ethnobiology, or ethnopaleontology, of the world of conodont studies. Knell is a museum studies specialist, and presents an account of a major mystery solved by paleontologists in field and museum.

I remember telling my wife, many years ago, "They found the conodont animal!!"

She said something like, "Huh?"

When I explained, her eyes glazed over and she found something else to attend to. The world is probably divided into those few hundred who worried about this animal and the other seven billion who did not. But the story makes fascinating reading for anyone interested in the classic ethnobiological question of how people classify life-forms and give names to them.

Conodonts first appeared as microscopic or nearmicroscopic fossils that looked like (what else?) little cone-shaped teeth. They first turned up in the mid$19^{\text {th }}$ century. More and more appeared, and Knell says there are now literally millions of them in collections around the world. Conodonts are extremely valuable to oil geologists and others who must give exact geological positions to specific strata.

But the conodonts were not attached to anything. They were disembodied presences. This led to enormous speculation. Were they from fish, primitive chordates, worms? One school even held that they were plant products (like overgrown phytoliths). More and more conodonts turned up, some simple, some fantastically elaborate in shape. Whole schools of conodont studies appeared, with their journals and learned volumes, and "conodontology" became a specialized field. Scholars debated whether to give the forms special form-class names (as trackways and burrows are named in Latin) or whether to stick to proper Linnaean names and hope an animal turned up to go with the teeth. Of course, with nothing but minute teeth to go on, scientists could not be sure whether they were dealing with genera, species, families.... Mammal paleontology experts will find this somewhat familiar, but with mammal teeth there are at least many living homologues. The conodonts were quite different from the teeth of any living animal.

Finally, in the 1980s, shadowy traces of condont animals began to appear, and by the early 1990s there were many of these, showing a small worm-shaped segmented animal with a notochord and something like a skull. It was clearly a primitive chordate, possibly an early vertebrate (there is still debate about whether to count it as a true vertebrate). It had rather large eyes, and swam around seizing prey with its savage little fangs.

The interest of this to ethnobiologists lies in the story of scientists coming slowly to understand an animal known only from very strange teeth. No anatomical dissection, no bone measurements, no physiological studies-let alone DNA. In other words, the scientists were pretty much on all fours with the Maya or Haida or Pintupi of a thousand years ago. They did the best they could: they interacted constantly with the fossils and their contexts, and then with other scholars studying same. They then came up with tentative plans, ideas, guesses, hypotheses, and tested them against data that emerged with painful slowness. They developed labels-of-convenience, and fought over even those. They argued over every new revelation. This book 
shows very clearly what scientists do when they cannot use their full range of laboratory techniques and manipulations. What they do is very similar to what skilled persons in traditional small-scale societies do. The differences between "bioscience" and "ethnoscience" are erased, or nearly so.

This is certainly thought-provoking. As a former biology student, I have always been struck by the basic uniformity of science. The many obvious differences between a modern DNA lab scientist and a Maya woodsman labeling a new bird seem to me quite superficial. What matters is that both are interacting with the biotic world to come to increasingly good understandings. Both use the same technique: interactive observation, with manipulation when possible. One has more specialized equipment, but both have basically the same eyes, hands, and brain. On the other hand, they come to quite different understandings in the end, because they have different scientific traditions. Similarly, different schools of conodont studies in different countries (or states of the US) produced very different ideas about the condont animal. Bioscience has its own cultures, and nationality affects these.

Knell grounds this understanding in the philosophy and history of science, with appropriate citations to Edmund Husserl, Thomas Kuhn, and the rest, but it is a point that can also be reached from cognitive psychology, as it has been in ethnoscience studies.

This book has been criticized for lack of illustrations and lack of much detail about the people involved. It is also rather a mixed bag in terms of intended audience: Sometimes Knell appears to be writing for the masses, sometimes he assumes the reader knows paleontology quite thoroughly. These problems should not stop a determined reader interested in finding out how people classify lifeforms as they slowly learn more and more about them. 